\title{
АЛГОРИТМ ВЫПОЛНЕНИЯ РЕВЕРСИВНОГО ЭНДОПРОТЕЗИРОВАНИЯ ПЛЕЧЕВОГО СУСТАВА ПРИ ДЕФИЦИТЕ КОСТНОЙ МАССЫ ЛОПАТКИ
}

\author{
Кесян Гурген Абавенович \\ Д.м.н., професссор, ФГБУ «НМИЦ ТО им. Н.Н. Приорова» \\ Минздрава России \\ Карапетян Григорий Сергеевич \\ К.м.Н., врач травматолог-ортопед, ФГБУ «НМИЦ ТО \\ им. Н.Н. Приорова» Минздрава России \\ Шуйский Артём Анатольевич \\ Acnuрант, ФГБУ «НМИЦ ТО им. Н.Н. Приорова»
Минздрава России
shuj-artyom@mail.ru \\ Уразгильдеев Рашид Загидуллович \\ Д.м.н., в.н.С., ФГБУ «НМИЦ ТО им. Н.Н. Приорова» \\ Минздрава России \\ Арсеньев Игорь Геннадьевич \\ К.м.н., С.н.С., ФГБУ «НМИЦ ТО им. Н.Н. Приорова» \\ Минздрава России \\ Кесян Овсеп Гургенович \\ К.м.Н., С.н.С., ФГБУ «НМИЦ ТО Им. Н.Н. Приорова» \\ Минздрава России
}

ALGORITHM FOR PERFORMING REVERSE SHOULDER ARTHROPLASTY IN PATIENTS WITH A DEFICIT OF SCAPULA BONE MASS

G. Kesyan

G. Karapetyan

A. Shuyskiy

R. Urazgil'deev

I. Arsen'ev

O. Kesyan

Summary. Purpose. To develop an algorithm of actions for shoulder arthroplasty with reverse implants in conditions of bone mass deficiency of the articular cavity of the scapula.

Material and methods. In the conditions of the 8th department of the N.N. Priorov National Research Medical Center of the Ministry of Health of the Russian Federation, reverse shoulder arthroplasty was performed in patients with bone mass deficiency of the articular cavity of the scapula, who were replaced with both marginal and extensive bone defects of the glenoid.

Results. On the basis of the conducted research, a consistent surgical tactic was developed to compensate for the lack of bone tissue of the scapula and to implant the components of a reversible shoulder endoprosthesis.

Conclusion. The developed tactics of actions for defects of the articular cavity of the scapula allows for reverse shoulder arthroplasty in these complex clinical cases, taking into account the disturbed anatomy of the shoulder joint.

Keywords: arthroplasty, reverse arthroplasty, autograft, osteoarthritis, omarthrosis.
Аннотация. Цель. Разработать алгоритм действий при эндопротезировании плечевого сустава имплантами реверсивного типа в условиях дефицита костной массы суставной впадины лопатки.

Материал и методы. В условиях 8 отделения ФГБУ «НМИЦ ТО им. Н.Н. Приорова» Минздрава России производилась реверсивная артропластика плечевого сустава пациентам с дефицитом костной массы суставной впадины лопатки, которым производилось замещение как краевых, так и обширных костных дефектов гленоида.

Результаты. На основании проведённого исследования разработана последовательная хирургическая тактика восполнения дефицита костной ткани лопатки и имплантации компонентов реверсивного эндопротеза плечевого сустава.

Заключение. Разработанная тактика действий при дефектах суставной впадины лопатки позволяет производить реверсивное эндопротезирование в данных сложных клинических случаях с учётом нарушенной анатомии плечевого сустава.

Ключевые слова: артропластика, реверсивное эндопротезирование, аутотрансплантат, остеоартроз, омартроз. 


\section{Ввемение}

$\mathbf{M}$ етодом оперативного лечения травм и заболеваний плечевого сустава, сопровождающихся выраженными изменениями анатомии суставных структур, является реверсивное эндопротезирование [1]. Учитывая такие положительные стороны реверсивной артропластики как смещение центра ротации сустава, улучшение натяжения и тонуса дельтовидной мышцы, показания данной операции расширяются с течением времени [2].

На основании литературных данных известно, что в 38\% случаев травматологи сталкиваются с дефицитом костной массы суставной впадины лопатки при выполнении реверсивного эндопротезирования плечевого сустава $[3,4]$. Подобные дефекты суставной впадины лопатки составляют большую сложность для корректной установки метаглена и гленосферы из-за трудностей интраоперационной дифференцировки истинной и ложной плоскости суставной поверхности.

Согласно литературным источникам, для таких случаев созданы специальные направляющие устройства, которые позволяют устанавливать метаглен в правильном положении по отношению к шейке лопатки [5]. В данных случаях недопустима медиализация гленосферы, а также нежелательно проведение ножки метаглена и фиксирующих винтов через зону дефекта вне костной ткани. Эта ошибка может привести к раннему вывиху эндопротеза. Возможно также нарушение компрессии метаглена к лопатке, нестабильность винтов и миграция лопаточного компонента. Известны методики восполнения дефицита костной ткани гленоида при помощи костной аутопластики из резецированной головки плеча или аллопластики, использования аугментов и модификации лопаточных компонентов эндопротеза [6]. Многие авторы указывают на то, что наиболее оптимальным костнопластическим материалом являются губчатые аутотрансплантаты, так как губчатая кость обладает высоким потенциалом для сращения и, соответственно, более выраженными остеогенными, остеоиндуктивными и остеокондуктивными свойствами $[7,8]$. Учитывая отсутствие общепризнанного чёткого алгоритма действий при данных сложных случаях, проблема реверсивного эндопротезирования плечевого сустава при дефектах суставной поверхности лопатки, является актуальной.

\section{Це^ь}

Разработка и оценка эффективности тактики действий при реверсивной артропластике плечевого сустава в условиях дефектов и дефицита костной массы суставной поверхности лопатки.

\section{материал и методы}

В условиях 8 отделения ФГБУ «НМИЦ ТО им. Н.Н. Приорова» Минздрава России производилась реверсивная артропластика плечевого сустава пациентам с дефицитом костной массы суставной впадины лопатки, которым производилось замещение как краевых, так и обширных костных дефектов гленоида.

В рамках предоперационного обследования пациента оценивался болевой синдром, объём движений в суставе, функциональное состояние дельтовидной мышцы. Принципиально важным методом исследования являлось проведение компьютерной томографии плечевого сустава с трёхмерным моделированием, так как на её основании производилась оценка объёма и методов предполагаемой реконструкции суставной впадины лопатки.

При наличии массивного дефицита костной массы суставной впадины лопатки и медиализации костной площадки для имплантации метаглена, необходимо проведение аутопластики трансплантатом значительного размера. После произведённого хирургического доступа к плечевому суставу суставную поверхность лопатки обрабатывали фрезой. Рассчитывали толщину трансплантата для необходимой латерализации суставной поверхности лопатки. Выполняли забор костного аутотрансплантата из гребня крыла подвздошной кости. Выполняли моделирование трансплантата, выполняли аутопластику концентрическим с ножкой метаглена значительного размера трансплантатом. Причем, установку трансплантата производили по направляющей спице, по которой через трансплантат рассверливали канал ножки метаглена. Метаглен устанавливали через центр аутотрансплантата в лопатку с учётом угла наклона суставной впадины и биомеханических данных пациента. Добивались достижения компрессии и плотного прилегания поверхностей всех элементов системы лопатка - трансплантат - метаглен по отношению друг к другу на удлинённой ножке метаглена без формирования «зазоров» и пустых пространств. Далее осуществляли проведение фиксирующих метаглен винтов, причем принципиальным являлось использование винтов необходимой длины через костный трансплантат в лопатку для обеспечения его компрессии, стабильности, ремоделирования и последующей консолидации с костной тканью.

При наличии краевых дефектов гленоида без медиализации всей суставной поверхности лопатки производилась их костная аутопластика, фиксация трансплантата с последующей установкой компонентов эндопротеза. Пластика краевых дефектов суставной поверхности лопатки выполняли следующим образом. Выполняли доступ к суставной поверхности лопатки, 
удаляли рубцовые ткани, суставной хрящ. Проводили визуальную, мануальную и инструментальную оценку параметров дефекта и определяли величину потери костной массы суставной впадины. Далее выполняли хирургический доступ к гребню подвздошной кости, остеотомом производили забор костного аутотрансплантата необходимой величины. Производили моделирование аутотрансплантата в зависимости от формы и размеров дефекта, осуществляли его имплантацию в зону дефекта. Выполняли остеосинтез трансплантата канюлированными металлическими или биорезорбируемыми винтами. Метаглен устанавливали с учётом угла наклона сформированной суставной впадины лопатки и биомеханических данных пациента. После достижения компрессии и плотного прилегания поверхностей всех элементов системы лопатка - трансплантат - метаглен фиксировали метаглен винтами. Принципиальным являлось проведение винтов необходимой длины в тело лопатки для обеспечения компрессии аутотрансплантата, его стабильности, перестройки и последующей консолидации с костной тканью лопатки. Даже после выполнения замещения небольших дефектов, целесообразно выбирать ревизионные метаглены с удлинённой ножкой для их более стабильной фиксации. Основополагающим является попадание длинной ножки метаглена в тело лопатки.

\section{Результаты}

На основании проведённого исследования разработана последовательная хирургическая тактика восполнения дефицита костной ткани лопатки и имплантации компонентов реверсивного эндопротеза плечевого сустава.

Проведено наблюдение за пациентами, которым была выполнена костная аутопластика суставной поверхности лопатки и последующее реверсивное эндопротезирование. У всех пациентов выявлено отсутствие вывихов эндопротеза на протяжении всего срока наблюдения. По данным компьютерной томографии выявлена перестройка и остеоинтеграция трансплантатов, без признаков нестабильности метаглена с винтами и фиксирующих трансплантат имплантов.

\section{Обсужмение}

Имплантация лопаточного компонента реверсивного эндопротеза на медиализированную суставную поверхность лопатки, приводит к осложнениям, связанным с нарушением центрации ножки протеза по отношению к гленосфере и отсутствием необходимого натяжения и тонуса дельтовидной мышцы [3]. Данные нарушения биомеханики при реверсивном эндопротезировании приводят к вывихам плечевого компонента [3].

Гребень крыла подвздошной кости в качестве донорской зоны забора трансплантата выбран нами с учётом того, что губчато-кортикальный трансплантат обладает необходимыми механическими свойствами, является оптимальным в плане репаративной регенерации и восстановления костной массы $[3,8]$. В похожих условиях губчатый трансплантат из резецированной головки плечевой кости обладает более податливой структурой и не обеспечивает необходимую механическую прочность для латерализации суставной впадины лопатки [6]. Более того, зачастую на фоне гиповаскулярных и дегенеративно-дистрофических изменений головка плечевой кости вовсе отсутствует. При некоторых заболеваниях и посттравматических изменениях проксимального отдела плечевой кости не удаётся произвести забор костной ткани и из этой зоны.

Решение проблемы дефицита костной массы суставной впадины лопатки при реконструктивных вмешательствах и эндопротезировании плечевого сустава, разработка тактики действий в зависимости от формы и объёма дефекта имеет большую практическую значимость [6].

\section{Зак^ючение}

Согласно нашему практическому опыту, в большинстве случаев причиной нестабильности метаглена и дислокации компонентов эндопротеза является некорректная имплантация лопаточного компонента с нарушением угла установки и офсета гленосферы. Разработанная тактика действий при дефектах суставной впадины лопатки позволяет производить реверсивное эндопротезирование в данных сложных клинических случаях с учётом нарушенной анатомии плечевого сустава.

\section{Конф^икт интересов}

Конфликт интересов не заявляется.

\section{ЛИТЕРАТУРА}

1. Frankle M, Marberry S, Pupello D. Reverse shoulder arthroplasty. Cham-Switzerland, 2016; $486 \mathrm{p}$.

2. Кесян Г.А., Уразгильдеев Р.З., Карапетян Г.С. и др. Реверсивное эндопротезирование плечевого сустава в сложных клинических случаях. // Вестник Смоленской государственной медицинской академии 2019; (4): 111-120 
3. Formaini N, Everding N, Levy J. The effect of glenoid bone loss on reverse shoulder arthroplasty baseplate fixation. J Shoulder Elbow Surg 2015; 6: 1-7.

4. Kyriacou S, Falworth M. The management of glenoid bone loss in shoulder arthroplasty. J Shoulder Elbow Surg 2018; 6: 21-30.

5. Грегори Т.М. Устройство эндопротезирования плечевого сустава. Патент РФ № 2569531. Опубликовано 27.11.2015. Бюллетень № 33

6. Seidl AJ, Williams GR, Boileau P. Challenges in reverse shoulder arthroplasty: addressing glenoid bone loss. Orthopaedics 2016; 39 (1): 14-23.

7. Анастасиева Е.А., Садовой М.А., Воропаева А.А., Кирилова И.А. Использование ауто- и аллотрансплантатов для замещения костных дефектов при резекциях опухолей костей (обзор литературы). Травматология и ортопедия Росии 2017; (3): 148-155.

8. Берченко Г.Н., Кесян Г.А., Уразгильдеев Р.З. и др. Сравнительное экспериментально-морфологическое исследование влияния некоторых используемых в травматолого-ортопедической практике кальцийфосфатных материалов на активизацию реперативного остеогенеза. Бюллетень ВСНц СО PAMH 2006; (4): 327-332.

( ) Кесян Гурген Абавенович, Карапетян Григорий Сергеевич,

Шуйский Артём Анатольевич ( shuj-artyom@mail.ru ), Уразгильдеев Рашид Загидуллович,

Арсеньев Игорь Геннадьевич, Кесян Овсеп Гургенович.

Журнал «Современная наука: актуальные проблемы теории и практики»

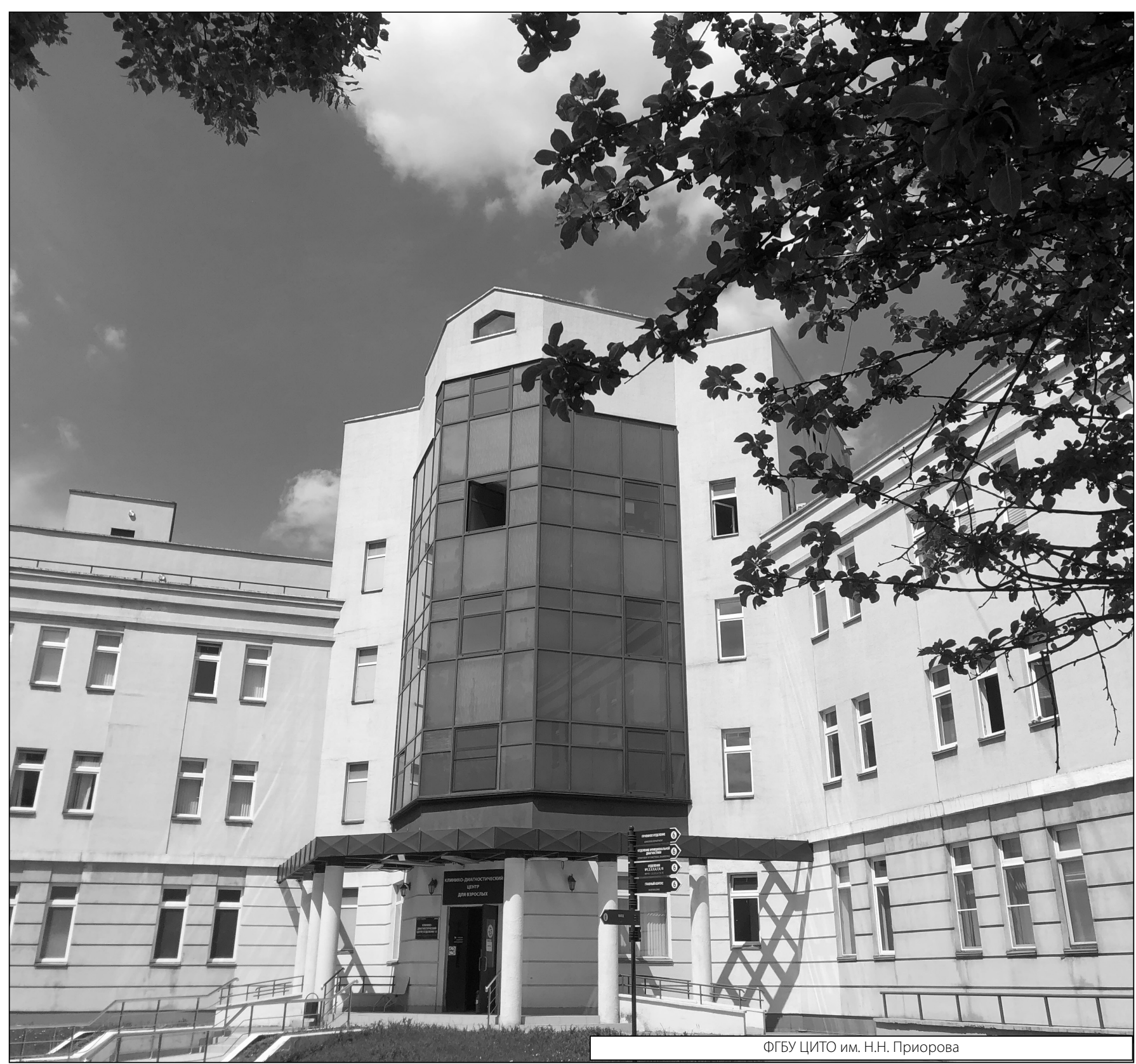

